Proceedings of the Institution of
Civil Engineers
Geotechnical Engineering 161
April 2008 Issue GE2
Pages $75-92$
doi: 10.1680/geng.2008.161.2.75
Paper 1491।
Received 10/08/2006
Accepted 05/06/2007
Keywords: environment/pollution/
urban regeneration

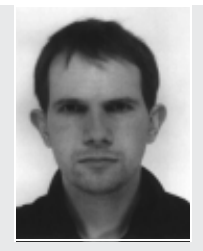

Michael J. Harbottle Research Associate, Department of Engineering. University of Cambridge, UK
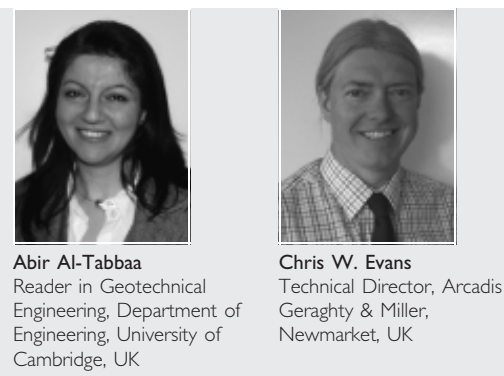

\title{
Sustainability of land remediation. Part I: overall analysis
}

M. J. Harbottle, DPhil, A. Al-Tabbaa, PhD, CEng, MICE, and C. W. Evans, PhD, CEng, MICE

A comparative assessment was carried out of the technical and environmental sustainability of five different contaminated land remediation projects completed in the UK between 1997 and 2002. The remediation technologies employed were in situ stabilisation/solidification, soil washing, ex situ bioremediation, cover system and excavation, and disposal to landfill. A further objective of the assessment was to highlight areas of sustainability concerns for the individual technologies and projects. The assessment is based around four principal criteria defined by the authors. Each project was assessed using both an overall multi-criteria analysis, detailed in this paper (Part I), and a study of the detailed impacts on an individual project basis, detailed in Part 2.

\section{INTRODUCTION}

The remediation of contaminated land is often considered to be a sustainable practice as it allows the reuse and redevelopment of previously developed land. However, most remediation methods involve a wide range of activities that result in environmental, social and economic impacts. The largest, most obvious impacts (particularly cost and duration) will usually be taken into account when selecting an appropriate technology to be used. However, potentially significant impacts (such as emissions or use of raw materials) can often be overlooked. There is a general consensus on which remediation technologies are sustainable (process-based technologies) and which are not (dig and dump). However, there has been little work on the relative sustainability of remediation techniques based on the assessment of their wider impacts.

The UK construction industry is becoming increasingly aware of the concept of sustainability, with broad-based government strategies being incorporated into industry thinking both on a national scale, through the Institution of Civil Engineers, and through individual companies down to individual sites. ${ }^{1}$ The UK government has produced objectives for sustainable development nationally, ${ }^{2}$ which have been translated into 'themes for action' specifically for the construction industry. ${ }^{3}$ The incorporation of sustainability into the design of remediation projects is increasingly being promoted through the above schemes and also through more focused systems. In Europe, for example, the Clarinet network has produced guidance on sustainable remediation, particularly the use of 'risk-based land management' and how sustainable practices can be included in this through the consideration of fitness for use, protection of the environment and long-term care. ${ }^{4,5}$

Assessment of the overall sustainability of any remediation technologies is yet to be presented in the literature, although some studies have looked at environmental impact, mostly applying a life cycle analysis (LCA) approach, as summarised by Suèr et al. ${ }^{6}$ Examples include Diamond et al. ${ }^{7}$ and Page et al., ${ }^{8}$ who presented a method that assessed the true impacts of excavation and disposal to landfill in terms of factors such as emissions, energy use and waste as well as human and ecological toxicity on one case study. They concluded that, among other effects, offsite transportation was a major cause of material use and emissions, and considered to a limited extent the potential effects on areas other than the remediated site itself. More recently Bayer and Finkel ${ }^{9}$ followed a similar approach in comparing a real funnel-and-gate project with a virtual pump-and-treat system for groundwater clean-up over time on the same site, concluding that the former method had long-term advantages whereas the latter had lower initial impacts. In both these cases considerable detail was available on the site considered, and hence the LCA was comprehensive, particularly in terms of human health effects, emissions, energy and materials used.

Blanc et al. ${ }^{10}$ and Volkwein et al. ${ }^{11}$ presented comparisons of the individual impacts of a number of techniques, both studies designed as selection tools on one particular site using projected data. In addition, Blanc et al. ${ }^{10}$ applied a limited multi-criteria analysis to their data, and their overall analysis concluded that excavation and disposal to landfill would have significant impacts in many categories of assessment, whereas onsite containment, using an onsite landfill cell, performed the best. Volkwein et al. ${ }^{11}$ highlighted how the required information for an LCA draws on many different sources and requires many assumptions to be made in a comparison of onsite landfilling, cover system (using asphalt) and decontamination (a combination of ex situ bioremediation, soil washing and thermal treatment). This study was an example of how such an analysis can be implemented, and deliberately does not draw definitive conclusions on the best technique for the site, but accepts that further non-technical issues would also have to be resolved prior to such a decision being made. Both Suèr et al. ${ }^{6}$ and Andersson ${ }^{12}$ assessed and compared a range of applications of similar techniques and found that the 
use of different assumptions meant that two assessment methods applied to the same project could come up with different suggested technologies.

Many of the published case studies are employed on a single site to be remediated in order to select the most sustainable remediation technique for that site. Such analyses usually rely on projected rather than actual data. In addition, most of those studies, if not all, highlighted the difficulty in attempting to consider a wide range of potential impacts owing to the enormity of the task and also the common lack of information in a number of areas.

This two-part publication presents an assessment and comparison of the technical/environmental sustainability of five remediation projects, performed in the UK between 1997 and 2002. The remediation technologies employed in these projects are: in situ stabilisation/solidification; soil washing; ex situ bioremediation; cover system and excavation; and disposal to landfill. Back-analysis of completed projects allows a realistic comparison, taking into account actual rather than projected impacts. A method has been developed by the authors for the purpose of performing this comparison that takes a wider view of the whole project using an overall multicriteria analysis, presented in this paper, as well as assessing individual impacts of remediation using detailed impact assessment, presented in Part 2 of this publication. ${ }^{13}$

The two methods of overall multi-criteria analysis and detailed impact assessment use an overlapping range of information, and complement each other. The multi-criteria analysis takes a broad overview of a remediation project, whereas the detailed impact assessment focuses on specific areas of impact. The multi-criteria analysis has the advantage that areas where little or no quantitative information is available can still be included. As a result, weightings and scores incorporate a degree of subjectivity, and hence including a sensitivity analysis allows a range of scores to be presented that take this subjectivity into account.

\section{ASSESSMENT OF TECHNICAL/ENVIRONMENTAL SUSTAINABILITY}

\subsection{Assessment criteria}

A method for performing sustainability assessment for the technical and environmental aspects of contaminated land remediation is presented here, based on Harbottle et al. ${ }^{14}$ Technical sustainability is defined as being concerned with the physical impacts arising due to the implementation of remediation. Social and economic effects have not been addressed directly, although their physical causes are included. This assessment is based around four principal criteria, as follows.

(a) Criterion 1: Future benefits outweigh cost of remediation. This requires any benefits of the remediation to outweigh any costs over the lifetime of the project and beyond. Benefits and costs measured in non-financial terms include: risks to site users and the public; the quality and quantity of surface water, groundwater, air and soil; the use of non-renewable resources; non-recyclable waste; and the potential range of future uses of the land. Financial benefits include the economic value of the land, the impact on surrounding areas, and incentives/tax breaks. Costs include capital, operation and maintenance, labour, site investigation, monitoring/post-closure maintenance, professional fees, insurance/legal and off-site disposal. This criterion is being addressed by the multi-criteria analyses presented in this paper.

(b) Criterion 2: The environmental impact of the remediation is less than the impact of leaving the land untreated.

(c) Criterion 3: The environmental impact of bringing about the remediation process is minimal and measurable.

(d) Criterion 4: The timescale over which the environmental consequences occur, and hence inter-generational risk, is part of the decision-making process.

Criteria 2, 3 and 4 are addressed by the detailed impact assessment presented in Part 2 of this publication. ${ }^{13}$

\subsection{Assessment technique: multi-criteria analysis (MCA)}

A number of decision support tools have previously been used or considered for use in selecting remediation technologies. ${ }^{15}$ Such techniques can be used for sustainability assessment and comparison. Two such methods are used in the work presented here. The first is an overall multi-criteria analysis (MCA), described in this paper, which was used to investigate the overall effect of remediation-that is, addressing criterion 1 above. The second is a detailed assessment of individual impacts, described in Part 2 of this publication, to investigate specific impacts by addressing criteria $2-4$.

The MCA method used here is based on that developed by Postle et al. ${ }^{16}$ for the Environment Agency. The basic method was originally designed to assist with the selection of appropriate technologies for contaminated land remediation on a given site, and has here been adapted to allow the comparison of the technical sustainability of remediation projects on different sites. It gives scores and weightings to assess the performance of a technology in different categories (human health and safety, environment, stakeholder concern and land use) and related subcategories. A sensitivity analysis was then employed in order to determine the effects of uncertainty on the scores and weights. Because it takes into account all areas of impact, this method was suitable for addressing criterion 1 above.

Compared with the original method, a number of extra subcategories have been included here, taking into account effects such as the use of raw materials and the production of waste. The 'environment' category has been subdivided into 'local environment' and 'global environment'. Also, effects onsite (directly related to the remediated site itself and its surrounding area) and offsite (any ancillary sites used, such as landfills, and travel to/from those sites) have been quantified separately. Scores and weightings have been developed using the process described below.

(a) Scores were determined on a scale of -100 to +100 , with 0 being no change from the original state, and -100 and +100 being the maximum negative and positive effects respectively. In each subcategory the project with the largest impact was selected and given the maximum score (positive or negative), and then scores for the other projects 
in that subcategory were determined relative to that project. Methods for determining the impacts, and hence the scores, are given in Section 4 (Results and Discussion, with further information in the Appendix.

(b) The weighting system involves application of weights at two stages:

(i) The most important criterion within a category was given a weighting of $1 \cdot 0$, and all others in the category weighted relative to this. Separate weights were used for onsite and offsite scores (weighting of scores during and after remediation was employed in the original method of Postle et al., ${ }^{16}$ but this was not performed here).

(ii) Corresponding scores and weights were multiplied and summed to give the category score.

(iii) Each category score was then normalised. For example, the human health and safety category had a maximum score of 800 (two subcategories with onsite, offsite, during and after scores). The total was divided by 8 to give an overall category score out of 100 .

(iv) The relative importance of categories for each site was determined by category weights, which were derived as described for subcategory weights. The total score for each site was then determined by combining category scores and weights and then summing.

Sensitivity analyses were performed in order to assess the effect of uncertainty on both the scores and the weights. The uncertainty in scoring was managed by investigating the outcome of a reasonable maximum and minimum set of scores for each site. Uncertainties in weightings were dealt with by preparing a number of different weighting sets based on the expected opinions of different stakeholders (in this case, nearby site residents, the developer, and residents near other sites used).

In order to allow direct comparison between the different projects and in different situations in a structured manner, a functional unit of 'per t of remediated soil' was used. The majority of studies in the literature used as a functional unit 'the treatment of a site', which is applicable only to the comparison or assessment of methods on a single site.

\section{SITE AND REMEDIATION PROJECT DETAILS}

The information used in this study was taken from remediation projects on different sites in the UK, which took place between 1997 and 2002. The data presented are therefore site-specific and not necessarily representative of the remediation technique in general. Summaries of the information used for each site are given below, with the data presented in Table 1 . The identities of the projects and sites are confidential, and hence the projects were identified by the remediation technique used. It should be noted that although a large amount of information was available for each project, a significant amount had to be derived from other sources. Details of common parameters used in both assessment techniques are given in the Appendix.

\section{I. Stabilisation/solidification (S/S)}

The site was contaminated because of past industrial use, and was located in a mixed-use area. Remediation by $\mathrm{S} / \mathrm{S}$ was implemented to allow residential reuse of the site.

Contaminants were present in layers of made ground, alluvium and gravels above an impermeable clay layer. A cementbentonite binder mix was used for the treatment. The soil was stabilised in situ up to a depth of $4.5 \mathrm{~m}$. The site was adjacent to a river, and a prime objective was to prevent its contamination. Distances to cement and bentonite suppliers were assumed based on distances to known production plants in the area. Leachate concentrations from S/S treated material were found to satisfy the remediation objectives set, and groundwater monitoring for a period of two years postremediation indicated a 98\% reduction in leached contaminant concentrations.

\subsection{Soil washing}

This site was a former gasworks with a nearby river. The future use of the site was expected to be commercial. The aims of this project were to prevent contamination of groundwater and the nearby river, and to minimise disturbance to surrounding residential areas over the duration of remediation. Hence soil washing was employed to remediate the site by removing finegrained soil material and the contamination contained within it, and by minimising waste. The soil stratigraphy consisted of made ground overlying alluvial material and gravels down to bedrock, with a range of organic and inorganic contamination primarily near the surface. Soil washing was the main remediation technique used, although material not considered suitable for reuse onsite was disposed of in landfill (including fines from the washing process). Contaminated made ground to approximately $1.5 \mathrm{~m}$, as well as deeper contaminated material, where practicable, was excavated and treated using an onsite soil washing plant. The actual landfill and borrow pit used in this project were not known, and so were assumed to be suitable local sites at the distances given in Table 1. Around 99\% of the batches of washed soil were found to satisfy the set remediation objectives, and those not passing were rewashed. Dust monitoring was employed during remediation.

\subsection{Ex situ bioremediation}

The site in question was used historically for a range of industrial purposes including a gasworks. It is in an urban setting, surrounded by a variety of land uses, and is adjacent to a river. Site soil, consisting of made ground and alluvium, was excavated and 32\% (with high concentrations of PCBs) was disposed of offsite by rail. The remainder was bioremediated onsite using windrows. The borrow pit used to supply fill material was not known: hence it was assumed to be a suitable local site. A range of residential and commercial uses was planned for the site. The majority of contamination was reduced to below the specified remediation targets, although occasional small areas at depth were left as they were not considered a risk. It was found that bioremediation was inexpensive but needed space, and was affected by the weather. During remediation, monitoring of dust, volatiles and odours was employed, and groundwater was monitored for two years following completion.

\subsection{Cover system}

This project consisted of hotspot excavation and tank removal on a former gasworks site followed by backfill (including reuse of clean excavated material) and then application of a cover. The amount of soil remediated by the cover system was considered to be that covered by the cap to a depth of $3 \mathrm{~m}$ (the maximum depth of hotspot excavation) and so was large 


\begin{tabular}{|c|c|c|c|c|c|}
\hline & $\begin{array}{l}\text { Stabilisation/ } \\
\text { solidification }\end{array}$ & Soil washing & Ex situ bioremediation & Cover system & Landfilling \\
\hline $\begin{array}{l}\text { Major } \\
\text { contamination* } \\
(\text { maximum in } \mathrm{mg} / \mathrm{kg} \text { ) }\end{array}$ & $\begin{array}{l}\text { BTEX (xylene to } \\
5000) ; \text { TPH }(8000)\end{array}$ & $\begin{array}{l}\text { PAH (I300); TPH } \\
\text { (7000); lead (3400) }\end{array}$ & $\begin{array}{l}\text { TPH (37 000); PAH } \\
\text { (7600); PCB (39); lead } \\
(1400)\end{array}$ & $\begin{array}{l}\text { PAH (I 20 000); lead } \\
\text { (I I 000); cyanide } \\
(44000) ; \text { mercury } \\
(200)\end{array}$ & $\begin{array}{l}\text { TPH }(58000) ; \text { lead } \\
(6 \mid 000) ; \text { arsenic } \\
(13000)\end{array}$ \\
\hline $\begin{array}{l}\text { Mass and fate of soil } \\
\text { remediated: }{ }^{\dagger} \mathrm{t}\end{array}$ & Onsite reuse: 7040 & $\begin{array}{l}\text { Landfill: } 108000 ; \\
\text { offsite reuse: } \\
\text { I I I00; onsite } \\
\text { reuse: } 158000\end{array}$ & $\begin{array}{l}\text { Landfill: } 25700 \text {; } \\
\text { bioremediation/onsite } \\
\text { reuse: } 56700\end{array}$ & $\begin{array}{l}\text { Landfill: } 190000 \\
\text { onsite reuse: } 882000\end{array}$ & Landfill: 4680 \\
\hline $\begin{array}{l}\text { Fate of soil } \\
\text { remediated: \% }\end{array}$ & Onsite reuse: 100 & $\begin{array}{l}\text { Landfill: } 39 \text {; offsite } \\
\text { reuse: } 4 \text {; onsite } \\
\text { reuse: } 57\end{array}$ & $\begin{array}{l}\text { Landfill: } 32 \text {; } \\
\text { bioremediation/onsite } \\
\text { reuse: } 68\end{array}$ & $\begin{array}{l}\text { Landfill: I3; onsite } \\
\text { reuse: } 87\end{array}$ & Landfill: 100 \\
\hline $\begin{array}{l}\text { Soil organic matter: } \\
\%\end{array}$ & 2 & $\begin{array}{l}2(15.5 \text { in waste } \\
\text { fines) }\end{array}$ & $2^{\oplus}$ & 2 & 17 \\
\hline $\begin{array}{l}\text { Materials used in } \\
\text { remediation: } \\
\mathrm{kg} / \mathrm{t} \text { soil }\end{array}$ & $\begin{array}{l}\text { Cement: } 43 \\
\text { bentonite: } 17\end{array}$ & Clean fill: 293 & $\begin{array}{l}\text { Nutrients } \\
\text { Clean fill: } 318\end{array}$ & $\begin{array}{l}\text { Geomembrane } \\
\text { Recycled fill: } 317\end{array}$ & Recycled fill: 1000 \\
\hline Water use & $\begin{array}{l}227 \mathrm{~kg} / \mathrm{t} \text { soil } \\
\text { remediated }\end{array}$ & $\begin{array}{l}112 \mathrm{~kg} / \mathrm{t} \text { soil } \\
\text { remediated }\end{array}$ & $\begin{array}{l}\text { Up to } 10 \mathrm{~m}^{3} \text { per day } \\
\text { per windrow }\end{array}$ & $\mathrm{N} / \mathrm{A}$ & $\begin{array}{l}1.9 \mathrm{~kg} / \mathrm{t} \text { soil } \\
\text { remediated }\end{array}$ \\
\hline $\begin{array}{l}\text { Distance to material } \\
\text { supply or disposal } \\
\text { site: } \mathrm{km}\end{array}$ & $\begin{array}{l}\text { Bentonite: } 88 \\
\text { cement: } 24\end{array}$ & $\begin{array}{l}\text { Borrow pit: } 24 ; \\
\text { landfill: } 8\end{array}$ & $\begin{array}{l}\text { Borrow pit: } 20 ; \\
\text { landfill: } 312 \text { (by rail) }\end{array}$ & $\begin{array}{l}\text { Borrow pit: I; landfill: } \\
\text { several landfills used }\end{array}$ & $\begin{array}{l}\text { Borrow pit: } 0 \text {; } \\
\text { (stockpiles on site); } \\
\text { landfill: } 12\end{array}$ \\
\hline Site plant used & $\begin{array}{l}2 \text { auger rigs }+ \\
\text { batching plant }\end{array}$ & $\begin{array}{l}4 \text { excavators, } 4 \\
\text { bulldozers/ } \\
\text { compactors, } 2 \\
\text { loaders, crusher, } 2 \\
\text { screens, soil } \\
\text { washing unit }\end{array}$ & $\begin{array}{l}4 \text { excavators, } 4 \\
\text { bulldozers/ } \\
\text { compactors, } 4 \text { loaders, } \\
\text { windrow turner, } 2 \\
\text { screens, crusher }\end{array}$ & $\begin{array}{l}5 \text { excavators, } 4 \\
\text { loaders, crusher, } 3 \\
\text { screens, } 5 \text { bulldozers/ } \\
\text { compactors }\end{array}$ & $\begin{array}{l}2 \text { excavators, } 2 \\
\text { bulldozers/ } \\
\text { compactors }\end{array}$ \\
\hline $\begin{array}{l}\text { Distance from plant } \\
\text { supply: km }\end{array}$ & 104 & 91 & 34 & 332 & 332 \\
\hline $\begin{array}{l}\text { Energy requirement } \\
\text { (other than vehicle } \\
\text { fuel) }\end{array}$ & $\begin{array}{l}0.154 \mathrm{~kg} \text { coal } / \mathrm{kg} \\
\text { cement, electricity } \\
\text { (clinker grinding)- } \\
30 \mathrm{kWh} / \mathrm{t}^{\S}\end{array}$ & $\begin{array}{l}\mathrm{I} \cdot 29 \mathrm{kWh} / \mathrm{t} \\
\text { electricity (assumed } \\
100 \mathrm{~kW} \text { soil washing } \\
\text { unit) }\end{array}$ & None considered & None considered & None considered \\
\hline $\begin{array}{l}\text { Duration of } \\
\text { treatment: months }\end{array}$ & 2 & 16 & II & 13 & 2 \\
\hline
\end{tabular}

*BTEX: benzene, toluene, ethylbenzene, xylene; TPH: total petroleum hydrocarbons; PAH: polycyclic aromatic hydrocarbons; PCB: polychlorinated biphenyls.

TWere volume only was known, converted to mass using assumed density of $1.6 \mathrm{t} / \mathrm{m}^{3}$.

Per t cement: $1 \cdot 10$ t limestone, $0.34 \mathrm{t}$ shale, $0.06 \mathrm{t}$ sand, $5 \mathrm{~kg}$ iron oxide. ${ }^{17}$

${ }^{\S}$ Coal-fired semi-wet/dry rotary kiln: approx. I Mcal per kg clinker formed, coal calorific value assumed to be $6.5 \mathrm{Mcal} / \mathrm{kg}$ (assumed all clinker ground to cement). ${ }^{17}$

TValue assumed.

Table I. Summary of relevant data for the five remediation projects considered

( 1.0 Mt). The cover consisted of approximately $1.0 \mathrm{~m}$ of clean granular material underlain by a geomembrane. The site has since been redeveloped for commercial use. Any impact on groundwater due to the treatment was to be minimised because of proximity to a major river: excavation below perched groundwater was avoided where possible. However, no cleanup of any contaminated groundwater was required, as the area surrounding the site was broadly contaminated and the source would not necessarily be on the site. All specified targets for contaminant reduction were reached. Monitoring consisted of dust and checks during remediation and groundwater for nine months afterwards.

\subsection{Excavation and disposal to landfill}

A variety of past industrial uses had left both organic and inorganic contamination on this relatively small site. The site was to be redeveloped for commercial/light industrial use. The soil stratigraphy comprised a layer of made ground overlying alluvium, gravel and sand layers. Hotspots of contamination in the made ground were excavated and disposed of to landfill. This was replaced by backfill using recycled material. The site was considered to have been successfully remediated. Groundwater and gas were monitored for a period of 18 months afterwards.

Flow diagrams highlighting the major stages of each remediation project are presented in Fig. 1 (details based on Diamond et al. ${ }^{7}$ ).

\section{RESULTS AND DISCUSSION}

\section{I. Categories, subcategories and weightings}

The categories, subcategories and related factors considered in each subcategory in the MCA analyses are shown in Table 2, and scores and weightings for the individual projects are presented in Tables 3-7 together with the results of the analysis. The weightings depended on the site, although there is a degree of consistency, particularly with category weightings. For example, 

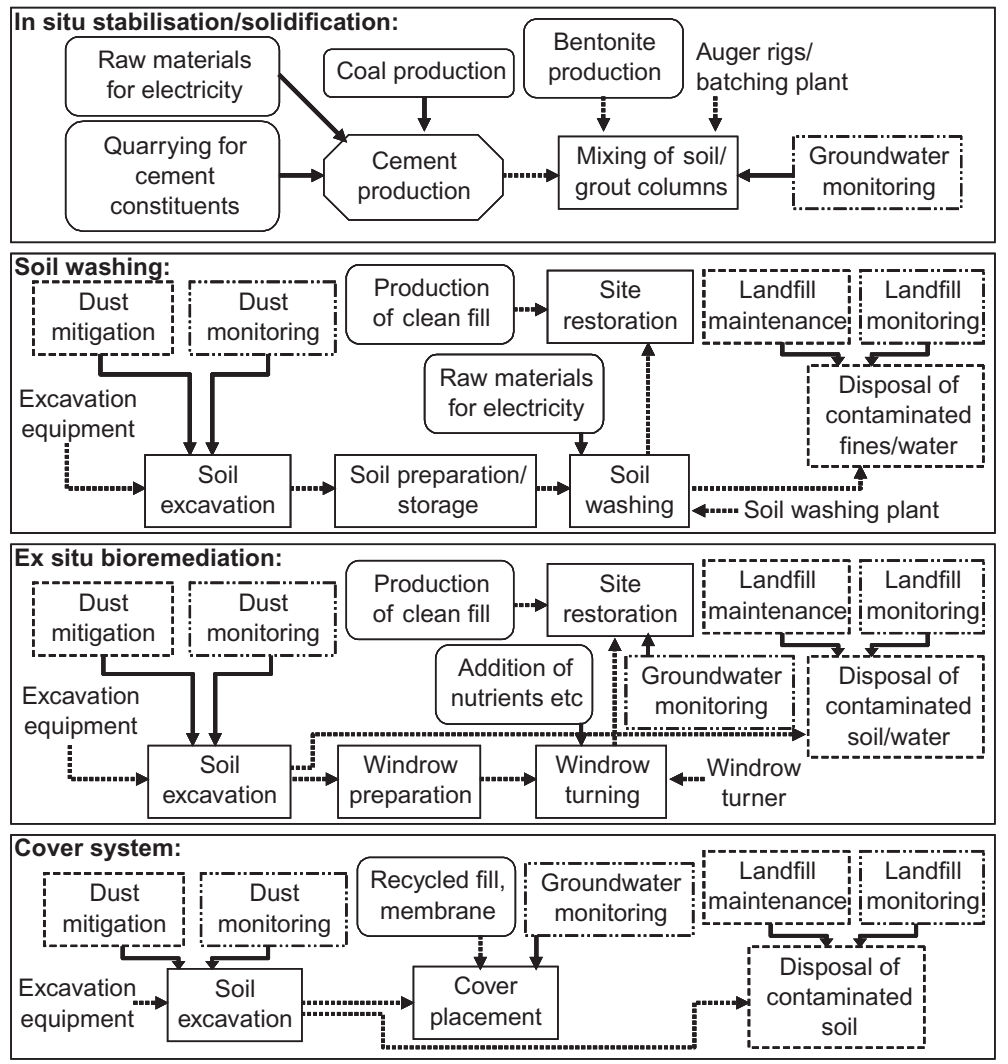

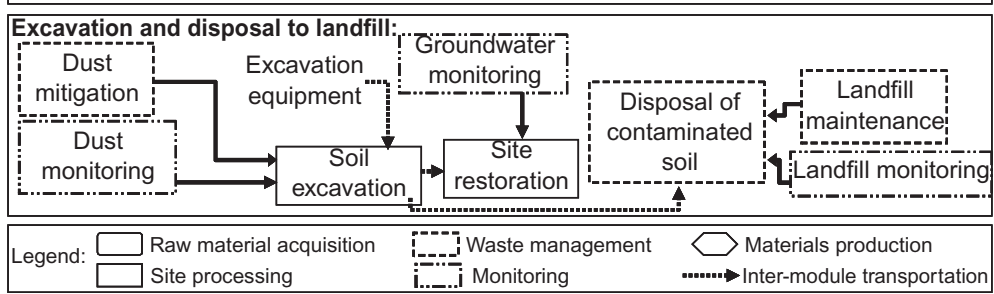

Fig. I. Flow diagrams for the five remediation projects, showing major remediation stages and inputs

contamination, and much of the area is industrial and commercial in nature. For the bioremediation project this category was given an intermediate weighting, because the site is in an urban location, although the impact on nearby surface and groundwater sources was not prioritised.

General trends are also evident in the subcategory weightings. In 'human health and safety', 'risks to site users' was given a higher weighting than that of 'risks to the public'. This was particularly the case with offsite locations, which were expected to be relatively isolated from the public. In 'local environment', air, surface and groundwater pollution were usually considered the most important subcategories both on and offsite. With 'site use', the remediation duration was usually considered most important onsite, whereas impact on landscape took precedence offsite. The three subcategories within 'global environment' were given equal weighting in all projects, as they are all non-site-specific in their importance. In general,

'site use' was given priority in all projects, as this was the main driver behind the remediation. It is closely followed by 'human health and safety', as this was the main risk to be reduced. In each case 'global environment' was given the lowest weighting, because, although it is likely to be considered important, it does not have the same immediate local impact as the other categories. The 'stakeholder concern' category has been included to allow the inclusion of social aspects in the analysis, as in Postle et al. ${ }^{16}$ However, while the 'acceptability' subcategory has been included, the 'confidence' subcategory has not owing to a lack of information. Indeed, the 'acceptability' subcategory has been considered only in a limited fashion in order to take into account the likely social impacts on the surrounding area, and therefore largely considered only stakeholders such as the public (including nearby residents) and developers. There would naturally be a large number of stakeholders from a wide variety of different backgrounds involved in each case, but information on this was largely unavailable. The 'local environment' category was the only category that was different for the various projects. It had the highest weighting for the

S/S and soil washing projects because of nearby surface and groundwater receptors, and it had the lowest weighting for the cover and disposal to landfill projects because the area surrounding these sites is generally degraded, with widespread the offsite weightings were less onerous than those for onsite, because the controlled nature of landfill sites and borrow pits and their usually relatively isolated location meant that the potential for harm from such risks can be controlled and reduced.

\subsection{Scores}

For certain subcategories [air quality ('pollution' and 'global warming'), duration of remediation, site use, natural resource use and waste] scores were derived directly from values calculated as part of the detailed impact analysis. ${ }^{13}$ Others were a combination of a range of effects measured both quantitatively and qualitatively, as described in Table 2. Certain subcategories (emissions and all those from the 'global environment' category) were taken to be onsite only, as this simplified the calculations. In addition, effects on ancillary sites were calculated by multiplying scores by the proportion of material involved on that site.

Scores arose from both quantitative and qualitative analysis, depending on the availability of data. Several of the subcategories were impossible to score exactly, and so some element of qualitative treatment was inevitable. A certain degree of subjectivity is therefore accepted as unavoidable, 


\begin{tabular}{|c|c|c|}
\hline Category & Subcategory & Factors \\
\hline \multirow[t]{2}{*}{ Human health and safety } & Risks to site users & $\begin{array}{l}\text { Intensity of site work (amount of soil excavated, placed, treated, } \\
\text { compacted etc.) and risk of contamination during operations } \\
\text { (qualitative). Contamination remaining (CLEA }{ }^{18,19} \text { analysis) }\end{array}$ \\
\hline & Risks to public & $\begin{array}{l}\text { Intensity of vehicle movements (no. HGVs/month), effect of transport } \\
\text { (mileage), contaminant escape (qualitative). }\end{array}$ \\
\hline \multirow[t]{7}{*}{ Local environment } & Surface water quality & Known or anticipated change to quality of surface water (qualitative) \\
\hline & Surface water quantity & Known or anticipated change to quantity of surface water (qualitative) \\
\hline & Groundwater quality & Known or anticipated change to quality of groundwater (qualitative) \\
\hline & Groundwater quantity & Known or anticipated change to quantity of groundwater (qualitative) \\
\hline & Air quality (pollution) & $\begin{array}{l}\text { Emissions impacts due to remediation (total BEES }{ }^{20} \text { emissions impact, } \\
\text { not including global warming), treated as all onsite }\end{array}$ \\
\hline & Quality/structure of soil & $\begin{array}{l}\text { Changes to properties and structure of soil (not including } \\
\text { contamination effects: qualitative) }\end{array}$ \\
\hline & Habitat/ecology & $\begin{array}{l}\text { Loss of habitat (number of soil, surface or water habitats lost } \\
\text { temporarily or permanently), effect of contamination on ecosystems } \\
\text { (contamination compared with ecological indicator benchmarks) }\end{array}$ \\
\hline \multirow[t]{2}{*}{ Stakeholder concern } & Confidence (not included) & $\begin{array}{l}\text { Level of trust that stakeholders hold in those involved in bringing } \\
\text { remediation about (e.g. regulators, contractors) }\end{array}$ \\
\hline & Acceptability & $\begin{array}{l}\text { Level of confidence of stakeholders in the remediation method } \\
\text { (qualitative) }\end{array}$ \\
\hline \multirow[t]{4}{*}{ Site use } & Duration of remediation & Length of remediation process \\
\hline & Impact on landscape & Impact on landscape (qualitative) \\
\hline & Site use & $\begin{array}{l}\text { Loss of site use during remediation (qualitative), range of potential } \\
\text { future uses of remediated and ancillary sites (from six categories: } \\
\text { agriculture, residential, industrial, commercial, green and non-green } \\
\text { open space) }\end{array}$ \\
\hline & Surrounding land use & $\begin{array}{l}\text { Impacts on surrounding land use due to inconvenience (likely during } \\
\text { remediation) and also benefits due to redevelopment (qualitative) }\end{array}$ \\
\hline \multirow[t]{3}{*}{ Global environment } & Air quality (global warming) & $\begin{array}{l}\text { Global warming emissions impact (from BEES analysis), treated as all } \\
\text { onsite }\end{array}$ \\
\hline & Use of natural resources & $\begin{array}{l}\text { Amount of natural resources used during remediation, treated as all } \\
\text { onsite }\end{array}$ \\
\hline & Waste & Amount of non-recycled waste disposed of, treated as all onsite \\
\hline
\end{tabular}

although every effort was made to overcome this through the use of the sensitivity analysis and presentation of justifications for scores and weightings.

The total project score is calculated as follows:

\begin{tabular}{|l|} 
Subcategory score $=$ \\
$($ onsite during + onsite after $) \times$ onsite weight \\
$+($ offsite during + offsite after $) \times$ offsite weight
\end{tabular}

Category score $=$
category weight $\times \sum \frac{(\text { subcategory scores })}{\text { normalisation factor }}$
(normalisation factor $=$
number of individual scores within category)
Total project score $=\sum$ (category scores)

The MCA results for each of the five remediation projects are presented in Tables 3-7, including all scores and weightings and their justifications.

\subsection{MCA results for the $S / S$ project}

Scores and impacts for the $\mathrm{S} / \mathrm{S}$ project are presented in Table 3 and summarised below for each category. The majority of impacts in this case were onsite.

(a) Human health and safety. Despite contaminants remaining onsite post-remediation, their availability was significantly reduced. Also, site operations and offsite movements were minimised. Long-term risks due to contamination were, however, uncertain. This is the only category that received a positive score for this project.

(b) Local environment. High emissions arose primarily from production of materials. The soil structure was disturbed, and would continue to be affected in the long term. A significant impact on any ecosystems on the site might be expected, owing to site operations, but the reduction of contamination risk was seen as positive in this respect. The highly negative onsite scores for those three subcategories led to this category having the second worst impacts for this project. On the other hand, groundwater contamination was found to be considerably reduced following remediation.

(c) Stakeholder concern. The continued presence of contaminants onsite was expected to have caused concern.

(d) Site use. Remediation was rapid, and the range of potential site uses was high. There was little impact on surrounding land use or landscape. 


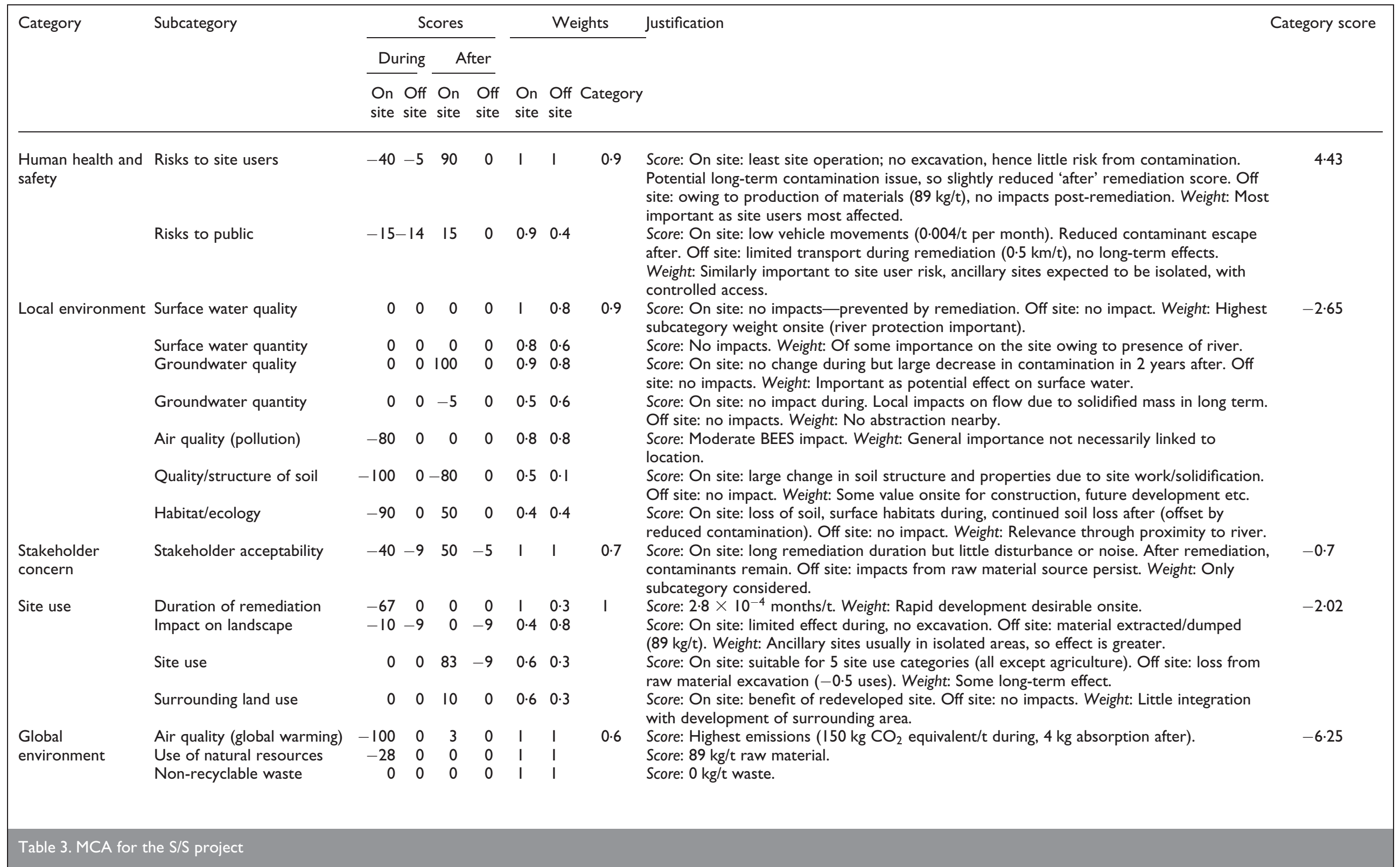




\begin{tabular}{|c|c|c|c|c|c|c|c|c|c|c|}
\hline \multirow[t]{3}{*}{ Category } & \multirow[t]{3}{*}{ Subcategory } & \multicolumn{4}{|c|}{ Scores } & \multicolumn{3}{|c|}{ Weights } & \multirow[t]{3}{*}{ Justification } & \multirow[t]{3}{*}{ Category score } \\
\hline & & \multicolumn{2}{|c|}{ During } & \multicolumn{2}{|c|}{ After } & \multirow[b]{2}{*}{$\begin{array}{l}\text { On } \\
\text { site }\end{array}$} & \multirow[b]{2}{*}{$\begin{array}{l}\text { Off } \\
\text { site }\end{array}$} & \multirow[b]{2}{*}{ Category } & & \\
\hline & & $\begin{array}{l}\text { On } \\
\text { site }\end{array}$ & $\begin{array}{l}\text { Off } \\
\text { site } s\end{array}$ & $\begin{array}{l}\text { On } \\
\text { site }\end{array}$ & $\begin{array}{l}\text { Off } \\
\text { site }\end{array}$ & & & & & \\
\hline \multirow[t]{2}{*}{$\begin{array}{l}\text { Human health and } \\
\text { safety }\end{array}$} & Risks to site users & -100 & -50 & 93 & -4 & I & I & 0.9 & $\begin{array}{l}\text { Score: On site: largest site operations, soil excavated. Low long-term contaminant risk. Off } \\
\text { site: } 695 \mathrm{~kg} / \mathrm{t} \text { extracted/dumped offsite (including contaminants). Small long-term } \\
\text { contaminant exposure risk. Weight: Most important as site users most affected. }\end{array}$ & -8.42 \\
\hline & Risks to public & $-16-$ & & 18 & -2 & 0.9 & 0.4 & & $\begin{array}{l}\text { Score: On site: during, low vehicle movement }(0.005 / \mathrm{t} \text { per month). After, contamination } \\
\text { reduced. Off site: fairly low transportation during }(\mathrm{I} \cdot \mathrm{l} \mathrm{km} / \mathrm{t}) \text {, small risk from landfilled } \\
\text { material. Weight: Nearby residential areas. Ancillary sites isolated with controlled access. }\end{array}$ & \\
\hline \multirow[t]{7}{*}{ Local environment } & Surface water quality & 0 & 0 & 0 & 0 & 1 & 0.8 & 0.9 & Score: No impacts. Weight: Particularly high weight onsite as river protection is important. & -5.41 \\
\hline & Surface water quantity & 0 & 0 & 0 & 0 & 0.8 & 0.6 & & Score: No impacts. Weight: Of some importance on the site owing to presence of river. & \\
\hline & Groundwater quality & -10 & 0 & 0 & -5 & 1 & 0.8 & & $\begin{array}{l}\text { Score: On site: contaminated groundwater produced onsite and disposed of during } \\
\text { remediation. Off site: potential long-term low level effects on landfill. Weight: No nearby } \\
\text { abstraction but important owing to potential effects on surface water. }\end{array}$ & \\
\hline & Groundwater quantity & -20 & 0 & 0 & 0 & 0.5 & 0.6 & & $\begin{array}{l}\text { Score: On site: dewatering of excavation. Off site: no impact. Weight: No abstraction } \\
\text { nearby. }\end{array}$ & \\
\hline & Air quality (pollution) & -96 & 0 & 0 & 0 & 0.8 & 0.8 & & Score: High BEES impact. Weight: General importance not necessarily linked to location. & \\
\hline & Quality/structure of soil & -100 & $-4-$ & -10 & 0 & 0.4 & 0.1 & & $\begin{array}{l}\text { Score: On site: all soil excavated, fines removed. After, loss of fines. Off site: compaction } \\
\text { on landfill. Weight: Some value onsite for future development. }\end{array}$ & \\
\hline & Habitat/ecology & -100 & & 70 & -8 & 0.4 & 0.4 & & $\begin{array}{l}\text { Score: On site: loss of soil and surface habitats through excavation. Restored afterwards. } \\
\text { Off site: loss of soil/surface habitat at borrow pit. Contained contaminants reduce long- } \\
\text { term score. Weight: Some relevance through proximity to river. }\end{array}$ & \\
\hline $\begin{array}{l}\text { Stakeholder } \\
\text { concern }\end{array}$ & Stakeholder acceptability & $-20-$ & & 90 & -20 & 1 & I & 0.7 & $\begin{array}{l}\text { Score: On site: low negative score as reduced vehicle movements. Good long-term score } \\
\text { as contamination and potential blight removed. Off site: concerns over of borrow pit/ } \\
\text { landfill. Continued concerns in long term. Weight: Only subcategory considered. }\end{array}$ & $-3 \cdot 33$ \\
\hline \multirow[t]{4}{*}{ Site use } & Duration of remediation & -13 & 0 & 0 & 0 & 0.6 & 0.3 & I & $\begin{array}{l}\text { Score: } 5.8 \times 10^{-5} \text { months/t. Weight: Duration not of importance for development, but still } \\
\text { important for neighbourhood. }\end{array}$ & $-2 \cdot 39$ \\
\hline & Impact on landscape & $-20-$ & & 0 & -69 & 0.4 & 0.8 & & $\begin{array}{l}\text { Score: On site: limited effect during remediation. Off site: determined by material } \\
\text { extracted/dumped }(695 \mathrm{~kg} / \mathrm{t}) \text {. Weight: Ancillary sites usually in isolated areas, so effect is } \\
\text { greater. }\end{array}$ & \\
\hline & Site use & 0 & 0 & 50 & -16 & 0.6 & 0.3 & & $\begin{array}{l}\text { Score: On site: three potential site uses (commercial, industrial, non-green open space). Off } \\
\text { site: effect of borrow pit/landfill ( }-1.0 \text { uses total). Weight: Some long-term effect. }\end{array}$ & \\
\hline & Surrounding land use & -1 & -1 & 70 & -20 & I & 0.3 & & $\begin{array}{l}\text { Score: On site: long-term benefit from blight removal. Off site: long-term negative effects } \\
\text { on landfill/borrow pit. Weight: Important onsite for removing blight. }\end{array}$ & \\
\hline \multirow{3}{*}{$\begin{array}{l}\text { Global } \\
\text { environment }\end{array}$} & Air quality (global warming) & -9 & 0 & 0 & 0 & 1 & I & 0.6 & Score: $14 \mathrm{~kg} \mathrm{CO} 2$ equivalent $/ \mathrm{t}$. & $-7 \cdot 25$ \\
\hline & Use of natural resources & -96 & 0 & 0 & 0 & i & i & & Score: $295 \mathrm{~kg} / \mathrm{t}$ raw material (primarily fill). & \\
\hline & Non-recyclable waste & -40 & 0 & 0 & 0 & 1 & I & & Score: $400 \mathrm{~kg} / \mathrm{t}$ waste. & \\
\hline
\end{tabular}




\begin{tabular}{|c|c|c|c|c|c|c|c|c|c|c|}
\hline \multirow[t]{3}{*}{ Category } & \multirow[t]{3}{*}{ Subcategory } & \multicolumn{4}{|c|}{ Scores } & \multicolumn{3}{|c|}{ Weights } & \multirow[t]{3}{*}{ Justification } & \multirow[t]{3}{*}{ Category score } \\
\hline & & \multicolumn{2}{|c|}{ During } & \multicolumn{2}{|c|}{ After } & \multirow[b]{2}{*}{$\begin{array}{l}\text { On } \\
\text { site }\end{array}$} & \multirow{2}{*}{\multicolumn{2}{|c|}{$\begin{array}{l}\text { Off Category } \\
\text { site }\end{array}$}} & & \\
\hline & & $\begin{array}{l}\text { On } C \\
\text { site si }\end{array}$ & $\begin{array}{ll}\text { Off } & \mathrm{O} \\
\text { site } & \text { si }\end{array}$ & $\begin{array}{l}\text { On } \\
\text { site }\end{array}$ & $\begin{array}{l}\text { Off } \\
\text { site }\end{array}$ & & & & & \\
\hline \multirow[t]{2}{*}{$\begin{array}{l}\text { Human health and } \\
\text { safety }\end{array}$} & Risks to site users & $-100-4$ & & 100 & -3 & 1 & I & 0.9 & $\begin{array}{l}\text { Score: On site: as for soil washing. Off site: } 625 \mathrm{~kg} / \mathrm{t} \text { material extracted/dumped offsite plus } \\
\text { exposure to contaminants on landfill. Small risk of contaminant exposure in long term. }\end{array}$ & $-5 \cdot 67$ \\
\hline & Risks to public & $-10-2$ & 251 & 18 & -2 & 0.8 & 0.4 & & $\begin{array}{l}\text { Score: On site: low vehicle movements }(0.003 / \mathrm{t} \text { per month). After, reduced risk of } \\
\text { contaminant escape. Off site: low transportation }(0.7 \mathrm{~km} / \mathrm{t}) \text {, small long-term risk from } \\
\text { contamination. Weight: Site isolated from residential areas but will be heavily used. } \\
\text { Ancillary sites expected to be isolated and with controlled access. }\end{array}$ & \\
\hline \multirow[t]{7}{*}{ Local environment } & Surface water quality & 0 & 0 & 0 & 0 & 1 & 0.8 & 0.7 & Score: No impacts. Weight: Highest weight onsite owing to river. & $-3 \cdot 33$ \\
\hline & Surface water quantity & 0 & 0 & 0 & 0 & 0.8 & 0.6 & & Score: No impacts. Weight: Of some importance on the site owing to presence of river. & \\
\hline & Groundwater quality & -10 & 0 & 0 & -5 & 0.8 & 0.8 & & $\begin{array}{l}\text { Score: On site: slight increase in contamination during remediation, returned to } \\
\text { background after. Off site: potential long-term low level effects on landfill. Weight: No } \\
\text { nearby abstraction but important owing to potential effects on surface water. }\end{array}$ & \\
\hline & Groundwater quantity & -20 & 0 & 0 & 0 & 0.5 & 0.6 & & $\begin{array}{l}\text { Score: On site: dewatering and removal of contaminated groundwater during. Off site: no } \\
\text { impact. Weight: No abstraction nearby. }\end{array}$ & \\
\hline & Air quality (pollution) & -80 & 0 & 0 & 0 & 0.8 & 0.8 & & $\begin{array}{l}\text { Score: Moderate BEES impact. Weight: Indicates general importance not necessarily linked } \\
\text { to location. }\end{array}$ & \\
\hline & Quality/structure of soil & $-100-$ & -3 & 5 & 0 & 0.4 & 0.1 & & $\begin{array}{l}\text { Score: On site: all material excavated, soil improved in windrows. Off site: compaction on } \\
\text { landfill. Weight: Of some value onsite for construction, future development. }\end{array}$ & \\
\hline & Habitat/ecology & $-100-1$ & 1610 & 100 & -6 & 0.4 & 0.4 & & $\begin{array}{l}\text { Score: On site: as for soil washing. Off site: as for soil washing. Weight: Some relevance } \\
\text { through proximity to river. }\end{array}$ & \\
\hline $\begin{array}{l}\text { Stakeholder } \\
\text { concern }\end{array}$ & Stakeholder acceptability & $-10-6$ & & 90 & -20 & 1 & I & 0.7 & $\begin{array}{l}\text { Score: On site: short project with transportation. After, most contaminants removed. Off } \\
\text { site: as for soil washing. Weight: Only subcategory considered. }\end{array}$ & -0.53 \\
\hline \multirow[t]{4}{*}{ Site use } & Duration of remediation & -31 & 0 & 0 & 0 & I & 0.3 & 1 & $\begin{array}{l}\text { Score: } 1 \cdot 3 \times 10^{-4} \text { months/t soil. Weight: Rapid redevelopment important: central urban } \\
\text { location. }\end{array}$ & $-1 \cdot 36$ \\
\hline & Impact on landscape & $-20-6$ & & $0-$ & -64 & 0.3 & 0.8 & & $\begin{array}{l}\text { Score: On site: limited effect during remediation. Off site: determined by material } \\
\text { extracted/dumped }(625 \mathrm{~kg} / \mathrm{t}) \text {. Weight: Ancillary sites usually in isolated areas, so effect is } \\
\text { greater. }\end{array}$ & \\
\hline & Site use & 0 & 08 & $83-$ & -22 & 0.6 & 0.3 & & $\begin{array}{l}\text { Score: On site: five potential uses (all except agriculture). Off site: effect of excavation/ } \\
\text { landfill (-I.3 uses). Weight: Some effect in long term. }\end{array}$ & \\
\hline & Surrounding land use & $-1-$ & $-1 \quad 10$ & $100-$ & -15 & 0.8 & 0.3 & & $\begin{array}{l}\text { Score: On site: part of redevelopment of surrounding area. Off site: long-term negative } \\
\text { effects on landfill/borrow pit. Weight: Important onsite as major part of area } \\
\text { redevelopment. }\end{array}$ & \\
\hline \multirow{3}{*}{$\begin{array}{l}\text { Global } \\
\text { environmentz }\end{array}$} & Air quality (global warming) & -11 & 0 & 0 & 0 & 1 & I & 0.6 & Score: $16 \mathrm{~kg} \mathrm{CO} 2$ equivalent/t. & $-7 \cdot 15$ \\
\hline & Use of natural resources & -100 & 0 & 0 & 0 & I & I & & Score: $313 \mathrm{~kg} / \mathrm{t}$ raw material (primarily fill). & \\
\hline & Non-recyclable waste & -32 & 0 & 0 & 0 & 1 & I & & Score: 312 kg/t waste. & \\
\hline
\end{tabular}




\begin{tabular}{|c|c|c|c|c|c|c|c|c|c|c|}
\hline \multirow[t]{3}{*}{ Category } & \multirow[t]{3}{*}{ Subcategory } & \multicolumn{4}{|c|}{ Scores } & \multicolumn{3}{|c|}{ Weights } & \multirow[t]{3}{*}{ Justification } & \multirow[t]{3}{*}{ Category score } \\
\hline & & \multicolumn{2}{|c|}{ During } & \multicolumn{2}{|c|}{ After } & \multirow[b]{2}{*}{$\begin{array}{l}\text { On } \\
\text { site }\end{array}$} & \multirow{2}{*}{\multicolumn{2}{|c|}{$\begin{array}{l}\text { Off Category } \\
\text { site }\end{array}$}} & & \\
\hline & & $\begin{array}{l}\text { On } \\
\text { site }\end{array}$ & $\begin{array}{l}\text { Off } \\
\text { site }\end{array}$ & $\begin{array}{l}\text { On } \\
\text { site }\end{array}$ & $\begin{array}{l}\text { Off } \\
\text { site }\end{array}$ & & & & & \\
\hline \multirow[t]{2}{*}{$\begin{array}{l}\text { Human health and } \\
\text { safety }\end{array}$} & Risks to site users & -85 & & 99 & -1 & I & 1 & 0.9 & $\begin{array}{l}\text { Score: On site: fairly large site operations; small amount of excavation but is most } \\
\text { contaminated. Off site: I } 26 \mathrm{~kg} / \mathrm{t} \text { material extracted/dumped offsite. Low contamination } \\
\text { risks during and after (small proportion of material to landfill). Weight: Most important as } \\
\text { site users most affected. }\end{array}$ & $-1 \cdot 19$ \\
\hline & Risks to public & -10 & -48 & 20 & -1 & 0.8 & 0.4 & & $\begin{array}{l}\text { Score: On site: lowest vehicle movements }(0.003 / \mathrm{t} \text { per month). Improvement through } \\
\text { contamination reduction afterwards. Off site: moderate transportation distance }(1.9 \mathrm{~km} / \mathrm{t}) \text {. } \\
\text { Very small risk from landfilled material afterwards. Weight: Site isolated from residential } \\
\text { areas but will be heavily used. Ancillary sites expected to be isolated and with controlled } \\
\text { access. }\end{array}$ & \\
\hline \multirow[t]{7}{*}{ Local environment } & Surface water quality & 0 & 0 & 0 & 0 & 0.8 & 0.8 & 0.6 & $\begin{array}{l}\text { Score: No impacts. Weight: Protection of river important but area is already generally } \\
\text { degraded. }\end{array}$ & -1.27 \\
\hline & Surface water quantity & 0 & 0 & 0 & 0 & 0.8 & 0.6 & & Score: No impacts. Weight: Of some importance on the site owing to presence of river. & \\
\hline & Groundwater quality & 0 & 0 & 0 & -5 & 0.8 & 0.8 & & $\begin{array}{l}\text { Score: On site: no impacts. Off site: potential long-term low level effects on landfill. Weight: } \\
\text { No nearby abstraction but some importance owing to potential surface water effects. }\end{array}$ & \\
\hline & Groundwater quantity & -20 & 0 & 0 & 0 & 0.5 & 0.6 & & Score: On site: excavation dewatering. Off site: no impacts. Weight: No abstraction nearby. & \\
\hline & Air quality (pollution) & -45 & 0 & 0 & 0 & 1 & 0.8 & & $\begin{array}{l}\text { Score: Low BEES impact. Weight: Indicates general importance not necessarily linked to } \\
\text { location. }\end{array}$ & \\
\hline & $\begin{array}{l}\text { Quality/structure } \\
\text { of soil }\end{array}$ & -13 & -1 & 0 & 0 & 0.4 & 0.1 & & $\begin{array}{l}\text { Score: On site: small proportion excavated. Off site: compaction on landfill. Weight: Of } \\
\text { some value onsite for construction, future development. }\end{array}$ & \\
\hline & Habitat/ecology & -50 & -7 & 80 & -3 & 0.3 & 0.4 & & $\begin{array}{l}\text { Score: On site: some loss of soil habitat, surface habitat lost through cover (largely } \\
\text { restored long term). Off site: loss of surface habitat on landfill (restored long term). } \\
\text { Weight: Some relevance through proximity to river. }\end{array}$ & \\
\hline $\begin{array}{l}\text { Stakeholder } \\
\text { concern }\end{array}$ & Stakeholder acceptability & $-10-$ & & 85 & -5 & 1 & I & 0.7 & $\begin{array}{l}\text { Score: On site: low negative impact as effect on local area is small, recycled materials are } \\
\text { used. Off site: as for soil washing. Weight: Only subcategory considered. }\end{array}$ & 9.98 \\
\hline \multirow[t]{3}{*}{ Site use } & $\begin{array}{l}\text { Duration of remediation } \\
\text { Impact on landscape }\end{array}$ & $\begin{array}{r}-3 \\
-20\end{array}$ & $\begin{array}{r}0 \\
-13\end{array}$ & $\begin{array}{l}0 \\
0\end{array}$ & $\begin{array}{r}0 \\
-13\end{array}$ & $\begin{array}{l}1 \\
0.3\end{array}$ & 0.3 & 1 & $\begin{array}{l}\text { Score: } 1.29 \times 10^{-5} \text { months/t. Weight: Rapid redevelopment most important. } \\
\text { Score: On site: limited effect during remediation. Off site: material extracted/dumped } \\
(126 \mathrm{~kg} / \mathrm{t}) \text {. Weight: Ancillary sites usually in isolated areas, so effect is greater. }\end{array}$ & 0.33 \\
\hline & Site use & 0 & 0 & 50 & 4 & 0.6 & 0.3 & & $\begin{array}{l}\text { Score: On site: three potential site uses (commercial, industrial, non-green open space). Off } \\
\text { site: effect of excavation/landfill ( }+0 \cdot 2 \text { uses). Weight: Will have some long-term effect. }\end{array}$ & \\
\hline & Surrounding land use & -1 & -1 & 10 & -7 & 0.7 & 0.3 & & $\begin{array}{l}\text { Score: On site: part of redevelopment of surrounding area. Off site: long-term negative } \\
\text { effects on landfill /borrow pit. Weight: Site part of area redevelopment. }\end{array}$ & \\
\hline Global & Air quality (global warming) & -6 & 0 & 0 & 0 & 1 & I & 0.6 & Score: Lowest emissions $(9 \mathrm{~kg} \mathrm{CO} 2$ equivalent $/ \mathrm{t})$. & -0.95 \\
\hline \multirow[t]{2}{*}{ environment } & Use of natural resources & 0 & 0 & 0 & 0 & I & I & & Score: I kg/t raw material. & \\
\hline & Non-recyclable waste & -13 & 0 & 0 & 0 & 1 & I & & Score: $125 \mathrm{~kg} / \mathrm{t}$ waste. & \\
\hline
\end{tabular}




\begin{tabular}{|l}
\hline Category Subcategory \\
\hline $\begin{array}{l}\text { Human health and Risks to site users } \\
\text { safety }\end{array}$
\end{tabular}

Risks to public

Local environment Surface water quality

$$
\text { Surface water quantity }
$$

Groundwater quality

Groundwater quantity

Air quality (pollution)

Quality/structure of soil

Habitat/ecology

Stakeholder acceptability

Duration of remediation Impact on landscape

\section{Site use}

Surrounding land use

Air quality (global warming) Use of natural resources Non-recyclable waste

Global

environmentz

Scores

Weights

Justification

During After

On Off On Off On Off Category

site site site site site site

$\begin{array}{lllll}-90-90 & 95 & -10 & 1 & 1\end{array}$

$\begin{array}{lllll}-100-100 & 18 & -5 & 0.7 & 0.4\end{array}$ $\begin{array}{lll}0 & 0.7 & 0.8\end{array}$

00

$\begin{array}{lll}0 & 0.5 & 0.6\end{array}$

$\begin{array}{lllll}-10 & 0-28 & -5 & 0.7 & 0.8\end{array}$

$\begin{array}{llllll}-5 & 0 & 0 & 0 & 0.5 & 0.6\end{array}$

$\begin{array}{cccccc}-100 & 0 & 0 & 0 & 1 & 0.8\end{array}$

$\begin{array}{lllll}-100-10 & 0 & 0 & 0.4 & 0.1\end{array}$

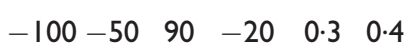

$-100-100100-30 \quad$ I I

$\begin{array}{rrrrrr}-100 & 0 & 0 & 0 & 1 & 0.3\end{array}$

$\begin{array}{llll}-20-100 & 0-100 & 0.3 & 0.8\end{array}$

$\begin{array}{llllll}0 & 0 & 50 & 33 & 0.6 & 0.3\end{array}$

$\begin{array}{llllll}-10 & -5 & 10 & -50 & 0.7 & 0.3\end{array}$

Table 7. MCA for the disposal to landfill project

0.9 Score: On site: all remediated material excavated, no processing onsite (so lower score than soil washing, bioremediation). Off site: $1002 \mathrm{~kg} / \mathrm{t}$ material extracted/dumped. Off site risks similar to those onsite. Weight: Most important as site users are most affected. Score: On site: highest number of vehicle movements ( $0.052 / t$ per month). Long-term improvement through contaminant removal. Off site: largest distance travelled $(3.6 \mathrm{~km} / \mathrm{t})$. Weight: Industrial future use, isolated from residential areas. Ancillary sites expected to be isolated and with controlled access.

0.6 Score: No impacts. Weight: Important to protect water courses but area was generally degraded, and site is some distance away from a river.

Score: No impacts. Weight: Moderate importance onsite; some distance from watercourse. Score: On site: contamination increase during remediation, further increase immediately after (potential long-term improvement). Off site: potential long-term low level effects on landfill. Weight: Of general importance but whole area degraded.

Score: On site: small amount of dewatering. Off site: no impacts. Weight: moderate; no abstraction nearby.

Score: Highest BEES impact. Weight: General importance not necessarily linked to location. Score: On site: all soil excavated. Off site: compaction on landfill. Weight: Of some value onsite for construction, future development.

Score: On site: loss of soil and surface habitat onsite, restored afterwards without contamination. Off site: loss of surface habitat on landfill, effects of contamination. Weight: Relatively unimportant.

0.7 Score: On site: highest negative impacts on local area. Off site: as for soil washing. Weight: Only subcategory considered.

I Score: $4.3 \times 10^{-4}$ months/t (slowest). Weight: Rapid redevelopment most important. Score: On site: limited effect during remediation. Off site: determined by material

extracted/dumped $(1002 \mathrm{~kg} / \mathrm{t})$. Weight: Ancillary sites usually in isolated areas, so effect is greater.

Score: On site: three potential site uses (commercial, industrial, non-green open space). Off site: effect of landfill (+2.0 uses). Weight: Will have some effect in long term.

Score: On site: part of redevelopment of surrounding area. Off site: long-term negative effects on landfill /borrow pit. Weight: Site part of area redevelopment.

0.6 Score: $18 \mathrm{~kg} \mathrm{CO}_{2}$ equivalent/t.

Score: $2 \mathrm{~kg} / \mathrm{t}$ raw material.

Score: $1000 \mathrm{~kg} / \mathrm{t}$ waste.
$-21 \cdot 87$ 
(e) Global environment. Emissions from cement production contributed to a high global warming impact, which led to this category having the worst impact. Use of resources was relatively low, and waste was negligible.

\subsection{MCA results for the soil washing project}

The scores for the soil washing project are presented in Table 4, with the following key impacts, leading to negative scores for all the categories.

(a) Human health and safety. Other than risks due to contamination, risks to site users arose predominantly as a result of the operations on the site and attendant vehicle movements, which were significant, leading to high negative scores and the highest negative score of all categories.

(b) Local environment. Pollutant emissions to the atmosphere were high, owing to both transportation and site work. Excavation of the site soil led to the high negative scores owing to its effect on soil structure and ecological impact, although the latter was considered to be improved in the long term through the removal of contamination. Those three subcategories led to the highest negative scores for the onsite activities during the remediation stage. The impact on surface and groundwater was minimal.

(c) Stakeholder concern. The reduced vehicle movements, compared with the situation if all material were disposed of offsite, were likely to have reduced concern about disturbance, although there were still impacts on the local area. As the site was cleaned, future opinion was likely to be positive.

(d) Site use. The landfilling element of the project had a large influence on landscape post-remediation. The proposed land use on the site was commercial/industrial, and so clean-up targets were not as stringent as for residential projects. The site was an important part of the surrounding area, and its redevelopment could be important for local prosperity: hence the high score in this subcategory in the long term. The category weight was not high, however, as development was not imminent.

(e) Global environment. The assumed use of virgin fill in this work led to a highly negative material use score. Waste was still a problem despite the measures taken to reduce it. This resulted in the second highest negative category score.

\subsection{MCA results for the ex situ bioremediation project} Table 5 contains scores for the ex situ bioremediation project, and highlights the following impacts in the various categories.

(a) Human health and safety. As with soil washing, excavation and movement of site soils led to a high site user risk during remediation, because of both contamination and operations. The reduction in contamination was sufficient to give the highest positive score for the post-remediation stage. Risks to the public were reduced through offsite transportation by rail. Because of the partly residential nature of the site development, risks to site users were considered most important. The remediation had the second highest negative impact on this category.

(b) Local environment. Air pollution was high, with site work and transportation being the main causes, and the excavation of the soil, as with soil washing, led to impacts on the structure of the soil and habitat at the site. The final state was considered to be similar to that initially, albeit with contamination removed, leading to a high positive future habitat score. The weighting for soil structure and habitat was low, however, owing to the initially industrial setting and taking into account the future site use.

(c) Stakeholder concern. As most of the work took place onsite, this project had a relatively low level of concern during remediation and positive impact post-remediation, since most of the contaminants were removed, resulting in the least negative category score.

(d) Site use. A high site use score was due to remediation to residential standards, giving more flexibility in future. Additionally, this project was part of the redevelopment of the surrounding area: hence the high score. Use of a landfill gave a negative impact on landscape offsite.

(e) Global environment. The assumed use of virgin fill led to a high negative score for material use, and waste was also high, although global warming emissions were low. This resulted in the highest negative score being for this category.

\subsection{MCA results for the cover system project}

Table 6 contains the MCA scores for the cover system project, which are summarised below. Many of the impacts here were reduced through normalisation, as a large volume of soil was considered to have been remediated.

(a) Human health and safety. Only contaminant hotspots were excavated, but other earthworks were considerable. Therefore risks to site users were still appreciable during the project. Although some contamination still remained onsite, there was found to be little risk to human health once the cover was installed. Risks to the public were caused primarily by offsite transportation.

(b) Local environment, Impact scores in this category were generally relatively low, as they were reduced through normalisation with respect to the large volume of soil remediated. Remediation was considered to have a positive future effect on the site habitat. This category received the highest negative score, although this was relatively low.

(c) Stakeholder concern. The relatively small impacts for such a large site led to a relatively low level of concern. The remediation was scored as being acceptable, although tempered by the knowledge that a low level of contamination remained beneath the cover. The score for this category was the highest of two positive scores.

(d) Site use. Landscape impacts arose offsite. The proposed site use (commercial) meant that the standard of remediation would not be sufficiently flexible to allow unfettered future development on the site. The site was part of the redevelopment of a large former industrial area, and so surrounding land use was an important subcategory.

(e) Global environment. Because of normalisation by weight of soil remediated, the impacts here are reduced. The use of recycled fill and minimisation of waste to landfill also minimised impacts.

\subsection{MCA results for the disposal to landfill project}

Scores describing the impacts from the disposal to landfill project are given in Table 7, showing all the category scores to be negative, and are summarised below. 
(a) Human health and safety. Risks to both public and site users were considered to be high in this case, as it had the largest proportion of soil disposed of offsite, and a large amount of soil excavation. Risks to the public were highest for all case studies because of the offsite disposal. This resulted in a relatively large negative score.

(b) Local environment. As in previous cases, excavation of the soil had impacts on soil structure and habitat. Groundwater was found to be impacted both during and immediately after remediation, although this was not considered particularly important owing to the degraded nature of the surrounding land. This had the smallest negative score.

(c) Stakeholder concern. The considerable amount of site work and disposal to landfill of all waste was expected to cause the most concern to other parties, resulting in a relatively large negative score.

(d) Site use. Per tonne of soil, this technique had the longest duration, although with this relatively small site, economies of scale might be less than in other cases.

(e) Global environment. Waste was highest of all case studies here, but use of material (owing to the use of recycled fill) and global warming emissions were relatively low.

\subsection{Sensitivity analyses}

Sensitivity analyses were carried out that took into account reasonable upper and lower bounds on the scores used in this study. This was determined primarily by how quantitative the data were for a particular category: scores derived from calculations were given little or no variability, whereas those with a qualitative background had more potential for subjectivity and so were given a higher potential variability. Therefore for scores determined directly from numerical data (e.g. air pollution) there was no variability, whereas with scores determined from qualitative information (e.g. impact on landscape) the variability might be \pm 10 or 20 (out of a total possible score of \pm 100 ). It is acknowledged that calculated data can also have uncertainty, depending on the quality of the data used, but this has not been considered here. The weights used in the sensitivity analyses took into account the likely views of nearby residents for both the remediated site and other involved sites, together with those of a developer. The values used in this part of the analysis are not presented here.

\subsection{Overall scores and comparisons}

The category scores and overall scores, developed from the results in Tables 3 to 7, are presented in Figs 2 and 3 respectively, together with the results from the sensitivity analyses represented by error bars. A comparison of the individual assessment categories between the five projects presented in Fig. 2 shows that

(a) in the 'human health/safety' category the in situ S/S project performed best and the landfilling project worst;

(b) in the 'local environment' and 'global environment' categories the cover system project performed best and the soil washing project worst;

(c) in the 'stakeholder concern' and 'site use' categories the cover system performed best and the landfilling project worst.

The variations in the outcome for each project from the sensitivity analyses shown in Figs 2 and 3 show that although

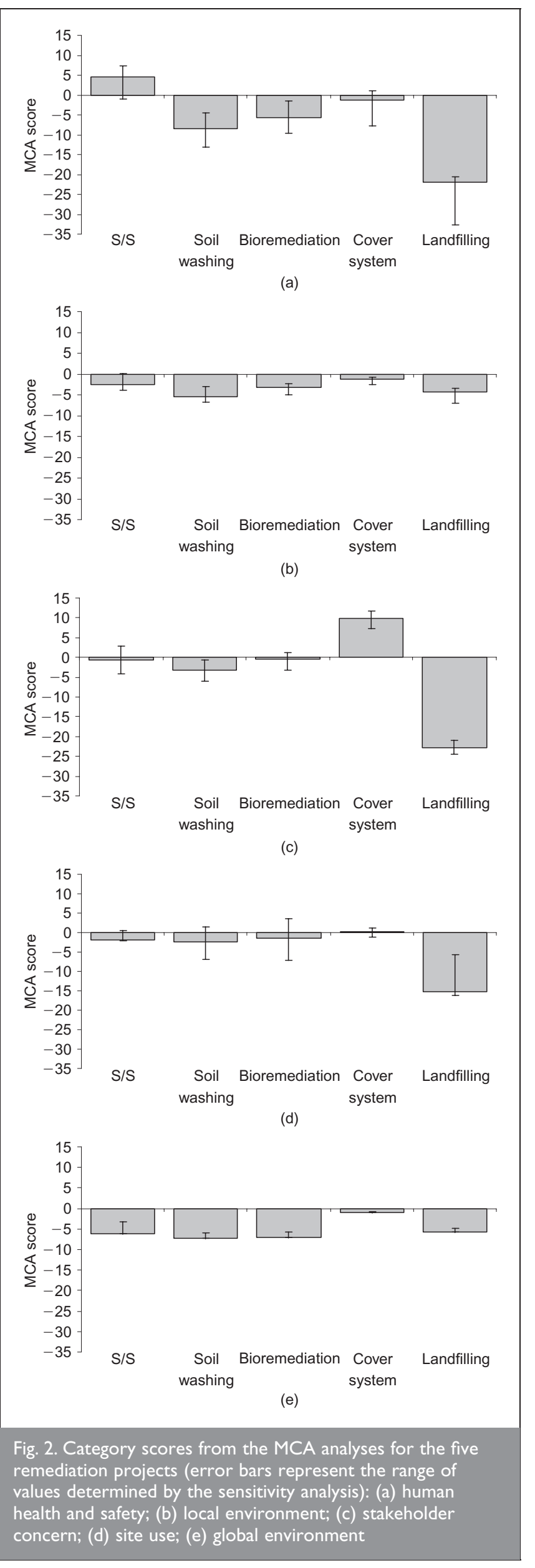

Fig. 2. Category scores from the MCA analyses for the five remediation projects (error bars represent the range of values determined by the sensitivity analysis): (a) human concern; (d) site use; (e) global environment 


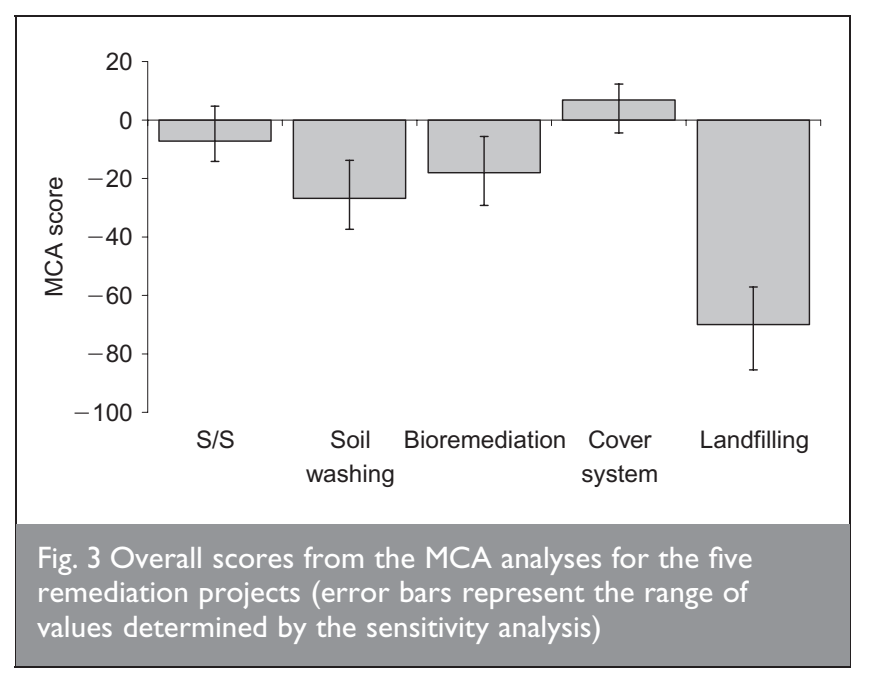

there is some overlap between the different technologies, this did not affect the overall conclusions of this study. 'Human health and safety' and 'site use' had the largest variability of the individual categories, while for the total scores the variability was consistent between the projects, although that for the cover system was slightly less. The level of variations is related to the level of information available for project and assessment category.

The MCA results show that the cover system project has the highest overall score and is hence considered the most sustainable from a technical/environmental viewpoint out of the five projects. The majority of impacts were not onerous, and the project had a high remediated volume of soil, which reduced impacts through use of the selected functional unit. On the other hand, the excavation and disposal to landfill project had the lowest overall score and is the least technically/ environmentally sustainable. The relatively good score for S/S was due primarily to the treatment being carried out in situ, minimising the impact on human health and the local environment, particularly with offsite effects. In all projects, apart from the S/S project, a certain proportion of the remediated soil was disposed of to landfill, and in the main it is this that led to the most onerous impacts. The main impacts of the soil washing and ex situ bioremediation projects were similar, and were particularly high in the categories of 'human health and safety', 'local environment' and 'global environment'.

It is also clear that the relative sustainability of a remediation project is dependent on the remediation criteria set. It is likely that the cover system project was ranked the most technically/ environmentally sustainable relative to the other projects because the issue of groundwater contamination was not important on that particular site, and hence a cover system solution was extremely effective in this case.

All the costs considered here are those in non-monetary terms. A final stage in the MCA would be to perform a costeffectiveness analysis incorporating the actual costs of the remediation. Those costs were unfortunately not available for the five projects considered here. However, examples of how the cost-effectiveness calculations could be used to compare the costs and benefits of remediation techniques are given in an earlier study by the authors ${ }^{14}$ and by Postle et al. ${ }^{16}$ There is also the potential for such an MCA method to be expanded to incorporate social effects, in order to provide a fuller assessment of the comparative sustainability of contaminated land remediation.

A general discussion combining the results from the MCA with those from the detailed impact analysis, presented in Part $2,{ }^{13}$ is presented in Part 2 of this publication, which highlights areas of sustainability concerns for the individual technologies and projects.

\section{CONCLUSIONS}

The multi-criteria analysis (MCA) performed on the five completed remediation projects highlighted the following.

(a) For the in situ S/S project there was an overall positive effect on human health and safety, whereas it had a negative impact on the local environment, stakeholder concern, site use and global environment, with the latter facing the worst impacts.

(b) For the soil washing project there was a negative impact on all five categories, with the impact on human health and safety being the worst and the impact on site use being the least onerous.

(c) For the ex situ bioremediation project there was a negative impact on all five categories, with the impacts on the global environment being the worst and the impacts on stakeholder concern being the least negative.

(d) For the cover system project there was a positive impact on stakeholder concern and-to a lesser degree-on site use. It had a slightly negative impact on the other three categories.

(e) For the excavation and disposal to landfill project there were negative impacts on all five categories, with the worst impacts on human health and safety and stakeholder concerns.

The conclusions are drawn only from the site-specific analyses used here, and not from the remediation technique in general. A comparison between the five remediation projects showed that the cover system project ranked the most technically/ environmentally sustainable. This was due primarily to the large volume of contaminated material that can be treated by this method. The in situ stabilisation/solidification project ranked second. This was due mainly to the process being performed in situ, with substantially reduced impacts in several areas. The ex situ bioremediation and soil washing projects ranked third and fourth respectively. Those two projects were found to provide benefits linked primarily to reducing the material taken to landfill, but had negative impacts linked to the risk to site users due to significant site operations, a range of impacts on the local environment and extensive use of raw materials. Not surprisingly the excavation and disposal to landfill project was ranked as the least technically/ environmentally sustainable. This was the case not only for the landfilling project but also where only a proportion of the soil was treated in this way, in combination with other remediation techniques. It was also clear from the analyses that the relative sustainability of a remediation project is dependent on the remediation objectives set. Comparative impacts highlighted in this study, together with those from the detailed impact assessment presented in Part 2, are discussed in Part 2 of this publication. 


\section{ACKNOWLEDGEMENTS}

The authors gratefully acknowledge the financial support of the UK Engineering and Physical Sciences Research Council (EPSRC) grant GR/S148809/01, through the SUBR:IM (Sustainable Urban Brownfield Regeneration: Integrated Management) research consortium, as well as Delta-Simons Ltd and May Gurney Ltd, who provided case study information for the analysis.

\section{APPENDIX. GENERAL INFORMATION USED IN THE ANALYSES}

The details of a number of parameters that were used in the analyses, in both Parts 1 and 2 of this publication, are given here. The information on these parameters was generally not sufficiently detailed or not available to allow accurate determination of site-specific factors. Also, information on methods used to calculate a number of impacts is presented.

\section{AI. Soil properties and site equipment}

A bulk density for the soil of $1600 \mathrm{~kg} / \mathrm{m}^{3}$ was assumed and the following information on ease of excavation for soils and raw materials was used to determine excavation rates and fuel consumption onsite. ${ }^{20}$

(a) 'easy dig' materials: virgin fill material (assume to be sand or gravel)

(b) 'medium dig' materials: site soil and bentonite

(c) 'hard dig' materials: limestone, shale, iron oxide, coal and uranium ore (for electricity production)
Site equipment data are presented in Table A1: they are either taken from or derived from Harris ${ }^{20}$ or use representative values. Excavation volumes and rates are calculated using a swelling factor (excavated volume divided by in situ volume) of 1.25 and a production loss (a factor accounting for a variety of incremental delays that prevent full output) of $40 \%$. The equipment used in each case was assumed based on information in the site reports (where specified) and the area of the site and volume of soil concerned. Noise was calculated using the method presented by Wills and Churcher. ${ }^{21}$ For this purpose it was assumed that the noisiest operations (usually excavation, screening and crushing) were taking place close to the site boundary. It was assumed in this calculation that, for stationary plant, the source is fully screened and that the receiver was close enough to a wall for reflection to occur. Table A1 lists the basic plant noise levels used.

\section{A2. Emissions}

Emissions from both short-term and long-term processes were considered. Short-term air emissions for a number of processes (listed in Table A2) are calculated using information from the UK National Air Emissions Inventory. ${ }^{22}$ In the long term, storage of materials containing organic matter in landfill can lead to methane generation due to anaerobic conditions. The amount of methane $\left(\mathrm{CH}_{4}\right)$ generated and emitted was calculated using the Intergovernmental Panel on Climate Change (IPCC) Tier Two methodology ${ }^{23}$ using standard values for typical modern landfills. Carbon dioxide $\left(\mathrm{CO}_{2}\right)$ emission due to the breakdown of the organic matter or oxidation of methane is

\begin{tabular}{|c|c|c|}
\hline \multirow[t]{3}{*}{ HGV/tipper truck } & Fuel consumption & $2.8 \mathrm{~km}$ per litre diesel \\
\hline & Capacity & $20 \mathrm{t}$ \\
\hline & Basic noise level & $106 \mathrm{~dB}$ \\
\hline \multirow{3}{*}{ Excavator } & Engine size & $80 \mathrm{~kW}$ \\
\hline & Fuel consumption & $20 \mathrm{l} / \mathrm{h}$ \\
\hline & Basic noise level & $105 \mathrm{~dB}$ \\
\hline \multirow[t]{3}{*}{$\mathrm{S} / \mathrm{S}$ auger rig } & Engine size & $80 \mathrm{~kW}$ \\
\hline & Fuel consumption & $20 \mathrm{l} / \mathrm{h}$ \\
\hline & Basic noise level & $108 \mathrm{~dB}$ \\
\hline \multirow[t]{6}{*}{ Bulldozer } & Engine size & $108 \mathrm{~kW}$ \\
\hline & Blade details & $3.2 \mathrm{~m}$ length, $4 \mathrm{~m}^{3}$ capacity \\
\hline & Fuel consumption & $23 \mathrm{l} / \mathrm{h}$ \\
\hline & Speed & $3 \mathrm{~km} / \mathrm{h}$ dozing speed, $6 \mathrm{~km} / \mathrm{h}$ return speed \\
\hline & Distance travelled & Assumed equal to twice radius of site (there and back) per load \\
\hline & Basic noise level & $109 \mathrm{~dB}$ \\
\hline \multirow[t]{4}{*}{ Wheeled loader } & Engine size & $153 \mathrm{~kW}$ \\
\hline & Fuel consumption & $26 \mathrm{l} / \mathrm{h}$ (average) \\
\hline & Shovel capacity & $3.6 \mathrm{~m}^{3}$ \\
\hline & Basic noise level & $109 \mathrm{~dB}$ \\
\hline \multirow[t]{4}{*}{ Compactor } & Details & Static weight roller, $3 \mathrm{~m}$ wide, performs 6 passes over $0.5 \mathrm{~m}$ lifts \\
\hline & Speed & 10 km/h \\
\hline & Fuel consumption & $23 \mathrm{l} / \mathrm{h}$ \\
\hline & Basic noise level & $109 \mathrm{~dB}$ (assumed towed by bulldozer) \\
\hline \multirow[t]{3}{*}{ Screen } & Throughput & $450 \mathrm{t} / \mathrm{h}$ (maximum) \\
\hline & Fuel consumption & $20 \mathrm{l} / \mathrm{h}$ \\
\hline & Basic noise level & $106 \mathrm{~dB}$ \\
\hline \multirow[t]{3}{*}{ Mobile crusher } & Throughput & $120 \mathrm{t} / \mathrm{h}$ (maximum) \\
\hline & Fuel consumption & $9 \mathrm{l} / \mathrm{h}$ \\
\hline & Basic noise level & $114 \mathrm{~dB}$ \\
\hline \multirow{3}{*}{$\begin{array}{l}\text { Batching plant } \\
\text { Soil washing plant }\end{array}$} & Basic noise level & $106 \mathrm{~dB}$ \\
\hline & Throughput & $25 \mathrm{t} / \mathrm{h}$ \\
\hline & Electrical power & $100 \mathrm{~kW}$ \\
\hline
\end{tabular}




\begin{tabular}{|ll|}
\hline Electricity generation* & Coal fired \\
& Fuel oil \\
& Natural gas \\
& Urban travel \\
Road transport & Motorway travel \\
& Freight \\
Rail transport & Plant emissions \\
Site works & Raw material quarrying \\
Raw materials & Cement production \\
& Plant emissions \\
\hline
\end{tabular}

*Assumed no net emissions from nuclear and renewable power generation.

Table A2. Processes included in the analysis for which air emissions have been quantified ${ }^{22}$

not considered, so there is an effective net loss of $\mathrm{CO}_{2}$ through the creation of methane.

Raw emissions data were combined to assess a range of impacts based on the Building for Environmental and Economic Sustainability (BEES) analysis method ${ }^{24}$

(a) global warming potential: $\mathrm{CO}_{2}, \mathrm{CH}_{4}$ and $\mathrm{N}_{2} \mathrm{O}$

(b) acidification potential: $\mathrm{NO}_{x}$ and $\mathrm{SO}_{2}$

(c) eutrophication potential: $\mathrm{NO}_{x}$ and $\mathrm{N}_{2} \mathrm{O}$

(d) criteria air pollutants: $\mathrm{NO}_{x}, \mathrm{SO}_{2}$ and particulates (PM10)

(e) human health: $\mathrm{SO}_{2}$, benzene, 1,3-butadiene, mercury and lead

(f) smog: $\mathrm{CH}_{4}$, $\mathrm{CO}$, non-methane volatile organic compounds, benzene, PM10, benzo(a)pyrene, $\mathrm{NO}_{x}$ and 1,3-butadiene

(g) ecological impact potential: $\mathrm{N}_{2} \mathrm{O}, \mathrm{NO}_{x}$, CO, non-methane volatile organic compounds, benzene, mercury, lead and benzo(a)pyrene.

Multiplication factors for substances in each group were used, ${ }^{24}$ as well as normalisation factors (US-specific) for each group, allowing comparison between different areas. In addition, the seven impact areas were weighted using factors used in the BEES methodology, as derived by the US Environmental Protection Agency Science Advisory Board. For example, the normalised and weighted global warming potential was calculated as follows.

Normalised and weighted global warming potential = $\left[\sum\right.$ (substance mass $\times$ specific global warming index $\left.)\right]$ Normalising factor $\times$ weight

Calculated for carbon dioxide, methane and nitrous oxide

Normalisation and weightings used were as listed in Table A3.

For the MCA scores the global warming impact was addressed separately from the other pollutant impacts, as the latter are more localised. In scoring the localised air emissions impact the remaining normalised and weighted impact scores were all summed. Therefore this particular score is weighted twice: once to determine the relative impacts of each component (as part of the BEES analysis), and once as part of the overall MCA.

\section{A3. Electricity use}

Electricity use was considered when it formed a major part of energy supply: hence this was the case only in the S/S project, for cement clinker grinding, and in the soil washing project.

Raw material use in the generation of electricity was calculated based on the proportion of electricity generation by different methods. According to UK electricity production statistics, ${ }^{25}$ production of electricity was in the following proportions: $37 \%$ natural gas; 34\% coal; 23\% nuclear; $2 \%$ petroleum products; $2 \%$ hydro/wind; and 1\% biomass/geothermal. Consumption of raw materials in electricity production was calculated in kg/kWh: 0.40 coal; $0 \cdot 29$ oil; $0 \cdot 26$ natural gas; and 0.08 uranium ore.

\section{A4. Future usability of the site}

The effect on future usability of all the project sites was determined based on six different categories of potential future use: green space, agricultural, residential, commercial, industrial, and non-green open space. The change in the number of potential future uses due to remediation was determined for the remediated site, the landfill and quarry or borrow pit and then summed, after normalisation by the amount of soil/excavated material involved for each site. The site was initially assumed to have no potential future uses because of the contamination. Waste was assumed to be disposed of in a landfill (such as a former quarry) which would otherwise not be usable in any of the six categories. Following remediation, possible uses included green and non-green open space. A borrow pit would initially be assumed to be pristine (all six categories possible), but following the remediation process (i.e. the extraction of material) this would be reduced to zero.

A5. Risk to humans and ecosystems from contamination The change in risk to humans due to soil contamination was assessed using the UK's Contaminated Land Exposure Assessment (CLEA). ${ }^{18,19}$ It determines the expected impact of contaminants on humans based on inhalation, oral and dermal contact pathways. The risk is presented as a ratio of average daily exposure (ADE) to index dose (ID) or tolerable daily exposure (TDI) (the level below which either minimal or no adverse effects are expected). Here, the ADE/ID ratio was calculated before and after remediation, and for each contaminant present. The maximum value afterwards was then divided by the maximum value beforehand to give an indication of the reduction in maximum risk. In most cases the soil conditions could be adequately modelled with the standard soil types in the program. However, an additional soil type was added to represent a stabilised/solidified soil, based on a clayey soil with low permeability and high $\mathrm{pH}$. Impact on ecosystems was measured relative to ecological indicator benchmarks. ${ }^{26}$

\section{A6. Transportation}

Transportation mileage and number of arrivals and departures onsite were used as a measure of disturbance, and the impact on other sites was quantified for comparison using the total amount of material either extracted or dumped offsite. All the projects, except for the S/S project and excavation and disposal to landfill, involved two remediation techniques, one of which was landfilling, and so the overall score for this measure was determined by adding the scores for the proportions of soil treated in different places. 


\begin{tabular}{|c|c|c|}
\hline Area & Normalisation factor & Weighting factor \\
\hline Global warming potential & $\begin{array}{l}25582.64 \mathrm{~kg} \mathrm{CO} 2 \text { equivalents/year per } \\
\text { capita }\end{array}$ & 0.11 \\
\hline Acidification potential & $\begin{array}{l}7800200 \text { moles } \mathrm{H}^{+} \text {equivalents/year } \\
\text { per capita }\end{array}$ & 0.05 \\
\hline Eutrophication potential & $19.21 \mathrm{~kg} \mathrm{~N}$ equivalents/year per capita & 0.05 \\
\hline Criteria air pollutants & 19200 microDALYs/year per capita & 0.06 \\
\hline Human health & $\begin{array}{l}\text { I } 28768.68 \mathrm{~kg} \text { toluene equivalents/year } \\
\text { per capita }\end{array}$ & 0.11 \\
\hline Smog & $\begin{array}{l}151.5 \mathrm{~kg} \mathrm{NO} \text { equivalents/year per } \\
\text { capita }\end{array}$ & 0.06 \\
\hline Ecological impact potential & $\begin{array}{l}81.65 \mathrm{~kg} \text { 2,4-dichlorophenoxyacetic } \\
\text { acid equivalents/year per capita }\end{array}$ & 0.11 \\
\hline
\end{tabular}

\section{REFERENCES}

1. BennetT J. and CRudgington A. Sustainable development: recent thinking and practice in the UK. Proceedings of the Institution of Civil Engineers-Engineering Sustainability, 2003, 156, No. 1, 27-32.

2. DEPARTMENT OF THE ENVIRONMENT, TRANSPORT AND THE REGIONS. A Better Quality of Life: A Strategy for Sustainable Development for the UK. HMSO, London, 1999.

3. Department of the EnVIRonment, TRANSPORT AND the REgIONS. Building a Better Quality of Life: A Strategy for More Sustainable Construction. HMSO, London, 1999.

4. VeGTER J. Sustainable contaminated land management: a risk-based land management approach. Land Contamination and Reclamation, 2001, 9, No. 1, 95-100.

5. Vegter J., Lowe J. and Kasamas H. (eds). Sustainable Management of Contaminated Land: An Overview. Umweltbundesamt, Vienna, Austria, 2002, CLARINET Report.

6. SUĖR P., NILSSON-PÅledAl S. and NORRMAN J. LCA for site remediation: a literature review. Soil and Sediment Contamination, 2004, 13, No. 4, 415-425.

7. DiAmOND M. L., PAGE C. A., CAMPBEll M., McKenna S. and LALL R. Life cycle framework for assessment of site remediation options: method and generic survey. Environmental Toxicology and Chemistry, 1999, 18, No. 4, 788-800.

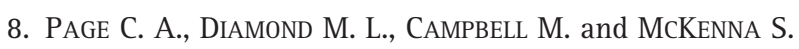
Life-cycle framework for assessment of site remediation options: case study. Environmental Toxicology \& Chemistry, 1999, 18, No. 4, 801-810.

9. BAYER P. and FINKEL M. Life cycle assessment of active and passive groundwater remediation technologies. Journal of Contaminant Hydrology, 2006, 83, No. 3-4, 171-199.

10. Blanc A., MÉTIVIER-Pignon H., Gourdon R. and RousSEAuX P. Life cycle assessment as a tool for controlling the development of technical activities: application to the remediation of a site contaminated by sulfur. Advances in Environmental Research, 2004, 8, No. 3-4, 613-627.

11. VOLKWEIN S., HuRTIG H.-W. and KLÖPFFER W. Life cycle assessment of contaminated sites remediation.

International Journal of Life Cycle Assessment, 1999, 4, No. 5, 263-274.

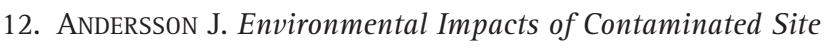
Remediation: A Comparison of Two Life Cycle Assessments. MSc thesis, Linköpings University, 2003.

13. Harbottle M. J., Al-TabbaA A. and Evans C. W.
Sustainability of land remediation. Part 2: Impact assessment. Proceedings of the Institution of Civil Engineers-Geotechnical Engineering, 2008, 161, No. 3, in press.

14. Harbottle M. J., Al-TabbaA A. and Evans C. W. Assessing the true technical/environmental impacts of contaminated land remediation: a case study of containment, disposal and no action. Journal of Land Contamination and Reclamation, 2006, 14, No. 1, 85-100.

15. BARDOS R. P., LEWIS A., NORTCLIFF S., Matiotti C., MAROT F. and Sullivan T. Review of Decision Support Tools for Contaminated Land Management and their Use in Europe. Umweltbundesamt, Vienna, Austria, 2002, CLARINET Report.

16. Postle M., Fenn T., Grosso A. and Steeds J. Cost-Benefit Analysis for Remediation of Land Contamination. Environment Agency, Bristol, UK, 1999, Scottish Environmental Protection Agency/Environment Agency R\&D Technical Report P316.

17. Hewlett P. C. (ed.). Lea's Chemistry of Cement and Concrete, 4th edn. Arnold, London, 1998.

18. ENVIRONMENT Agency. The Contaminated Land Exposure Assessment (CLEA) Model: Technical Basis and Algorithms. Environment Agency, Bristol, UK, 2002, CLR10.

19. EnVironment Agency. CLEA UK. Environment Agency, Bristol, UK, 2005, SCH01105BJPY-E-C.

20. HARRIS F. Modern Construction and Ground Engineering Equipment and Methods. Longman Scientific and Technical, Harlow, 1994.

21. Wills A. J. and ChURcher D. W. How Much Noise Do You Make? A Guide to Assessing and Managing Noise on Construction Sites. CIRIA, London, 1999, CIRIA Project Report 070.

22. UK NATIONAL ATMOSPHERIC EMisSiOnS INVENTORY. 2000 data. See www.naei.org.uk/emissions/selection.php (last accessed February 2008).

23. Gregory R. G., Gillett A. G. and Bradley D. Methane Emissions from Landfill Sites in the UK. Land Quality Management, Nottingham, 2003, Report for the Department for the Environment, Food and Rural Affairs.

24. LIPPIAT B. C. Building for Environmental and Economic Sustainability (BEES): Technical Manual and Users Guide. US National Institute of Standards and Technology, Gaithersburg, MD, 2002, NISTIR 6916, 4-29.

25. OfFicE OF NATIONAL STATISTICS. Electricity generation: by 
fuel used, EU comparison, 2001. Social Trends, 2001, 34,

Table $11 \cdot 13$

26. OAK RIDGE NATIONAL LABORATORY. Ecological Benchmark
Tool. United States Department of Energy, Oak Ridge, TN, USA, 2006. See http://rais.ornl.gov/cgi-bin/eco/ECO_select (last accessed February 2008).

\section{What do you think?}

To comment on this paper, please email up to 500 words to the editor at journals@ice.org.uk

Proceedings journals rely entirely on contributions sent in by civil engineers and related professionals, academics and students. Papers should be 2000-5000 words long, with adequate illustrations and references. Please visit www.thomastelford.com/journals for author guidelines and further details. 